\title{
Descriptions of Prevotella tannerae sp. nov. and Prevotella enoeca sp. nov. from the Human Gingival Crevice and Emendation of the Description of Prevotella zoogleoformans
}

\author{
L. V. H. MOORE,* J. L. JOHNSON, AND W. E. C. MOORE \\ Department of Biochemistry and Anaerobic Microbiology, Virginia Polytechnic Institute \\ and State University, Blacksburg, Virginia 24061-0305
}

\begin{abstract}
Prevotella tannerae sp. nov. and Prevotella enoeca sp. nov. from the human gingival crevice are described. These organisms are obligately anaerobic, non-spore-forming, nonmotile, gram-negative, rod-shaped bacteria that ferment carbohydrates and produce succinic and acetic acids. Bile inhibits growth. Some strains $(38 \%)$ of $P$. tannerae produce colonies with a tan to black pigment when they are grown on rabbit blood agar. The type strains are $P$. tannerae ATCC 51259 and $P$. enoeca ATCC 51261. In addition, the description of Prevotella zoogleoformans is emended to exclude strains now recognized as members of Prevotella heparinolytica.
\end{abstract}

During quantitative and qualitative studies of the bacterial flora of samples obtained from the human gingival crevice, we isolated numerous strains of anaerobic, gram-negative, rodshaped bacteria that represent species unlike any that have been described previously. Two of these organisms, designated "Bacteroides D28" and "Bacteroides D84" in our laboratory, were selected for further taxonomic study.

In addition, we propose that the description of Prevotella zoogleoformans should be emended to exclude strains now recognized as members of Prevotella heparinolytica. In 1938 Prévot described a new genus, Capsularis, with Capsularis zoogleiformans (Weinberg et al. 1937) as the type species (12). Because there was no strain to represent this species, it was not included on the 1980 Approved Lists of Bacterial Names (15). Following isolation from the gingival crevice of strains with the characteristics of "C. zoogleiformans," Cato et al. proposed the name Bacteroides zoogleoformans (Weinberg et al. 1937) (corrig.) comb. nov. (2). In 1988 Bailey et al. (1) showed that some strains originally thought to be $B$. zoogleoformans strains by Cato et al. and other strains whose characteristics corresponded to the characteristics of Bacteroides zoogleoformis (Weinberg et al. 1937) Cato et al. exhibited only 47 to $52 \%$ DNA relatedness with the type strain of $B$. zoogleoformans and concluded that these organisms should be members of a distinct species. Bailey et al. named the new species Bacteroides heparinolyticus and showed that strains of $B$. heparinolyticus produce indole and strains of $B$. zoogleoformans do not. Both species were transferred to the genus Prevotella (13), but an emended description of $P$. zoogleoformans that includes only the indole-positive strains has not been published previously. An emended description based on five indole-positive strains is given below.

\section{MATERIALS AND METHODS}

Bacterial strains. In this study we examined Prevotella tannerae ("Bacteroides D28") ATCC $51259^{\mathrm{T}}$ (American Type Culture Collection, Rockville, Md.) ( $\mathrm{T}=$ type strain), which was isolated from the gingival crevice of an adult with gingivitis, and 47 other isolates obtained from 38 samples from the gingival crevices of 33 other people (10 juveniles or adults with healthy gingiva, 4 people with gingivitis, 16 people with adult

\footnotetext{
${ }^{*}$ Corresponding author. Phone: (703) 231-7110. Fax: (703) 231-
}

periodontitis, 2 people with juvenile periodontitis, and 1 person with rapidly progressive periodontitis).

We also examined Prevotella enoeca ("Bacteroides D85") ATCC $51261^{\mathrm{T}}$, which was isolated from the gingival crevice of a person with adult periodontitis, and seven other isolates obtained from six other people (four juveniles or adults with healthy gingiva, one person with adult periodontitis, and one person with juvenile periodontitis).

$P$. zoogleoformans ATCC $33285^{\mathrm{T}}$ and four other strains isolated from people with adult periodontitis were also included in this study.

Type strains of other species were also examined for comparison (Table 1).

Characterization of strains. Fermentation, enzymatic, and antimicrobial agent susceptibility tests in prereduced media and polyacrylamide gel electrophoresis of soluble proteins were performed as described previously $(3,9)$. The fatty acid methyl ester contents of whole-cell sediments obtained from prereduced anaerobically sterilized peptone-yeast extract-glucose broth cultures were determined as described previously (8).

DNA isolation and hybridization. Strains were grown in

TABLE 1. Levels of DNA relatedness among some Prevotella species

\begin{tabular}{lccc}
\hline & \multicolumn{3}{c}{$\%$ Homology with reference DNA } \\
from:
\end{tabular}

${ }^{a}$ Value normalized to $100 \%$.

${ }^{b}$ NT, not tested. 
TABLE 2. Characteristics of $P$. tannerae, $P$. enoeca, and $P$. zoogleoformans ${ }^{a}$

\begin{tabular}{|c|c|c|c|c|c|c|}
\hline \multirow[b]{2}{*}{ Characteristic } & \multicolumn{2}{|c|}{ P. tannerae } & \multicolumn{2}{|c|}{ P. enoeca } & \multicolumn{2}{|c|}{ P. zoogleoformans } \\
\hline & $\begin{array}{c}\text { Reaction of } \\
\text { ATCC } 51259^{\mathrm{T}}\end{array}$ & $\begin{array}{c}\% \text { of } 47 \text { other } \\
\text { strains that } \\
\text { are positive }\end{array}$ & $\begin{array}{l}\text { Reaction of } \\
\text { ATCC } 51272^{\mathrm{T}}\end{array}$ & $\begin{array}{l}\% \text { of } 7 \text { other } \\
\text { strains that } \\
\text { are positive }\end{array}$ & $\begin{array}{l}\text { Reaction of } \\
\text { ATCC } 33285^{\mathrm{T}}\end{array}$ & $\begin{array}{l}\% \text { of } 4 \text { other } \\
\text { strains that } \\
\text { are positive }\end{array}$ \\
\hline \multicolumn{7}{|l|}{ Acid produced from: } \\
\hline Amygdalin & - & 0 & - & 0 & - & 50 \\
\hline Cellobiose & - & 0 & - & 0 & A & 75 \\
\hline Dextrin & A & 70 & A & 100 & A & 100 \\
\hline Fructose & A & 79 & A & 88 & A & 100 \\
\hline Gum arabic & - & 11 & - & 0 & - & 0 \\
\hline Glycogen & $\mathrm{A}^{b}$ & 81 & A & 100 & A & 0 \\
\hline Inulin & - & 11 & - & 0 & A & 0 \\
\hline Lactose & A & 81 & A & 100 & A & 0 \\
\hline Larcharabino-galactan & - & 5 & - & 0 & - & 0 \\
\hline Maltose & $\mathrm{A}^{b}$ & $81^{b}$ & A & 100 & A & 100 \\
\hline Mannose & A & 46 & A & 71 & A & 75 \\
\hline Melibiose & - & 4 & - & 0 & A & 50 \\
\hline Pectin & - & 17 & - & 42 & - & 0 \\
\hline Raffinose & A & 21 & - & 0 & A & 25 \\
\hline Salicin & - & 0 & - & 0 & A & 100 \\
\hline Starch & $\mathrm{A}^{b}$ & $83^{b}$ & A & 86 & A & 100 \\
\hline Sucrose & A & 30 & - & 0 & A & 75 \\
\hline Trehalose & $\mathrm{A}^{b}$ & $26^{b}$ & - & 0 & - & 100 \\
\hline Xylose & - & 0 & - & 14 & A & 0 \\
\hline \multicolumn{7}{|l|}{ Hydrolysis of: } \\
\hline Esculin & - & 15 & - & 43 & + & 100 \\
\hline Starch & $+^{b}$ & $83^{b}$ & + & 57 & - & 0 \\
\hline \multicolumn{7}{|l|}{ Digestion of: } \\
\hline Gelatin & + & 100 & + & 100 & + & 25 \\
\hline Milk & + & 76 & - & 0 & - & 0 \\
\hline Meat & - & 36 & - & 0 & - & 0 \\
\hline Milk curd & - & 27 & + & 100 & + & 75 \\
\hline Nitrate reduction & - & 4 & - & 0 & - & 0 \\
\hline $\begin{array}{l}\mathrm{H}_{2} \mathrm{~S} \text { (Simmons indole motility } \\
\text { medium) }\end{array}$ & + & 21 & - & 43 & + & 50 \\
\hline \multicolumn{7}{|l|}{$\begin{array}{l}\text { Peptone-yeast extract-glucose agar } \\
\text { deep }\end{array}$} \\
\hline Gas & - & 0 & - & 44 & - & 0 \\
\hline Reducing & - & 0 & - & 0 & + & 0 \\
\hline \multicolumn{7}{|l|}{ Resistance to: } \\
\hline Chloramphenicol $(12 \mu \mathrm{g} / \mathrm{ml})$ & - & 12 & - & 0 & - & 0 \\
\hline Clindamycin $(1.6 \mu \mathrm{g} / \mathrm{ml})$ & - & 4 & - & 0 & - & 0 \\
\hline Erythromycin $(3 \mu \mathrm{g} / \mathrm{ml})$ & - & 4 & - & 0 & - & 0 \\
\hline Penicillin $\mathrm{G}(2 \mathrm{U} / \mathrm{ml})$ & - & 17 & - & 28 & - & 0 \\
\hline Tetracycline $(6 \mu \mathrm{g} / \mathrm{ml})$ & + & 30 & - & 0 & - & 0 \\
\hline
\end{tabular}

${ }^{a} \mathrm{~A}$, acid $(\mathrm{pH}<5.5) ;-, \mathrm{pH}>5.7$ or negative reaction; +, positive reaction. All strains produced acid from glucose. No strain produced acid from arabinose, erythritol, esculin, mannitol, melezitose, rhamnose, ribose, or sorbitol; no strain produced lecithinase or lipase on egg yolk agar (3), indole, or catalase.

${ }^{b}$ This reaction may be positive or acid when serum $(10 \%, \mathrm{vol} / \mathrm{vol})$ is added to the medium but usually is not positive in the absence of serum.

peptone-yeast extract-glucose broth (3) supplemented with $1 \%$ (wt/vol) dehydrated brain heart infusion (Difco Laboratories, Detroit, Mich.). The DNA was isolated by using a variation of the Marmur procedure (7). DNA hybridization values were determined by using ${ }^{125}$ I-labeled reference DNAs and the S1 nuclease assay procedure (7). Each reassociation vial contained 3 to $5 \mathrm{ng}$ (about $30,000 \mathrm{cpm}$ ) of labeled DNA, $20 \mu \mathrm{g}$ of unlabeled DNA, and $6 \times \mathrm{SSC}(1 \times \mathrm{SSC}$ is $0.15 \mathrm{M} \mathrm{NaCl}$ plus $0.015 \mathrm{M}$ sodium citrate) containing $1 \mathrm{mM}$ HEPES $(N-2-$ hydroxyethylpiperazine- $N^{\prime}$-ethanesulfonic acid) (pH 7.0). Each reassociation experiment was performed for $24 \mathrm{~h}$ at $65^{\circ} \mathrm{C}$.

\section{RESULTS AND DISCUSSION}

"Bacteroides D28" and "Bacteroides D84" are anaerobic, fermentative, gram-negative bacilli that do not grow well in the presence of $20 \%$ bile and have phenotypic characteristics similar to those of Prevotella species (Tables 2 and 3). The major cellular fatty acids of these organisms also are similar to those found in members of the genus Prevotella (Table 4), with anteiso- $\mathrm{C}_{15: 0}$ fatty acid making up 30 to $36 \%$ of the total fatty acids detected. The $\mathrm{G}+\mathrm{C}$ contents of the DNAs (45 and 47 mol\%) are within the range found for other species in the genus Prevotella (5). These two closely related species exhibited negligible levels of DNA-DNA reassociation with Prevotella nigrescens, Prevotella melaninogenica, Prevotella denticola, and Prevotella oris (Table 1), species which are similar to them in cellular fatty acid content.

Because the characteristics of "Bacteroides D28" and "Bacteroides D84" are unlike the characteristics of previously described Prevotella species, we propose the following new species for these taxa: Prevotella tannerae and Prevotella enoeca, respectively.

Description of Prevotella tannerae sp. nov. Prevotella tannerae (tan'ne.rae. N. L. gen. n. tannerae, of Tanner, in honor of Anne 
TABLE 3. Differentiation of $P$. tannerae, $P$. enoeca, and $P$. zoogleoformans from indole-negative Prevotella species $^{a}$

\begin{tabular}{|c|c|c|c|c|c|c|c|}
\hline Species & Cellobiose acid & Esculin hydrolysis & Glycogen acid & Lactose acid & Sucrose acid & Meat digestion & Reference(s) \\
\hline$P$. disiens & - & - & A & - & - & + & 4 \\
\hline P. bivia & - & - & A & 93 & - & + & 4 \\
\hline P. enoeca & - & 38 & A & A & - & - & \\
\hline P. tannerae & - & 14 & 81 & 81 & 31 & 35 & \\
\hline P. oulora & - & + & $--^{b}$ & A & A & - & 16 \\
\hline P. zoogleoformans & 83 & + & $-^{c}$ & 17 & 67 & - & \\
\hline P. melaninogenica & 15 & 84 & A & A & A & - & 17 \\
\hline P. denticola & 22 & + & A & A & A & 15 & 17 \\
\hline P. veroralis & 80 & + & A & A & A & - & 16,17 \\
\hline P. oralis & A & + & A & A & A & - & 5 \\
\hline P. buccalis & A & + & A & A & A & - & 16 \\
\hline P. oris & A & + & A & A & A & - & 6 \\
\hline P. buccae & A & + & A & A & A & - & 6 \\
\hline
\end{tabular}

${ }^{a}-, 90$ to $100 \%$ of the strains are negative;,+ 90 to $100 \%$ of the strains are positive; A, 90 to $100 \%$ of the strains produce $\mathrm{pH}<5.7$. The values are the percentages of strains that are positive.

${ }_{b}^{b}$ Contrary to the original description (14), we have not been able to demonstrate that the type strain of Prevotella oulora lowers the pH of media containing glycogen unless serum (which contains amylase) is added to the medium. We realize that there has been confusion concerning the type strain of this species (11), but the tests for fermentation of glycogen were performed with the correct type strain obtained from the American Type Culture Collection in 1993 rather than with the strain that has been shown to be Rikenella microfusus (11).

${ }^{c}$ This reaction may be acid when serum is added to the medium.

C. R. Tanner, a United States microbiologist). The description below is based on studies of the type strain and 47 other isolates obtained from 37 other people. Cells of the type strain from peptone-yeast extract-glucose broth cultures are $0.3 \mu \mathrm{m}$ wide by 0.7 to $8.0 \mu \mathrm{m}$ long; filaments up to $14 \mu \mathrm{m}$ long are observed. Cells occur in short chains and are not motile. Surface colonies on blood agar plates incubated for 2 days are $1 \mathrm{~mm}$ in diameter, circular, low convex, and translucent to transparent. On rabbit blood agar medium, $19 \%$ of the strains are black, $19 \%$ are tan to brown to red, and the rest are colorless after incubation for 5 days. Colonies in pure cultures of 2 of 41 strains are surrounded by small clear zones of hemolysis.

Broth cultures are cloudy with a smooth sediment. The terminal $\mathrm{pH}$ values of glucose broth cultures after incubation for 5 days are 4.8 to $5.3 ; 53 \%$ of the strains require the addition of $10 \%$ sterile serum to broth media for optimum growth and acid production.

The fermentation acids are succinic acid $(2.6 \pm 0.22 \mathrm{meq} /$ $100 \mathrm{ml}$ of culture [mean \pm standard error of the mean]), acetic acid $(1.5 \pm 0.11 \mathrm{meq} / 100 \mathrm{ml})$, formic acid $(0.17 \pm 0.03 \mathrm{meq} / 100$ $\mathrm{ml})$, isovaleric acid $(0.15 \pm 0.03 \mathrm{meq} / 100 \mathrm{ml})$, and isobutyric acid $(0.03 \pm 0.006 \mathrm{meq} / 100 \mathrm{ml})$. No hydrogen is produced.

Additional characteristics of the species are shown in Tables 2 and 4.

Isolated from the human gingival crevice (Table 5) (10).

The type strain is ATCC 51259 (= VPI N14B-15).
The $\mathrm{G}+\mathrm{C}$ content of the DNA of the type strain is $45 \mathrm{~mol} \%$. Phenotypically, $P$. tannerae can be differentiated from many saccharolytic Prevotella species by the inability of most strains to hydrolyze esculin ( $86 \%$ of the strains are negative) and by the inability of most strains to ferment sucrose (69\% of the strains are negative) (Table 3). It differs from Prevotella bivia by not digesting meat and from the new species $P$. enoeca by its cellular fatty acid profile (iso- $\mathrm{C}_{15: 0}$ fatty acid content) (Table 4).

Description of Prevotella enoeca sp. nov. Prevotella enoeca (e.noe'ca. Gr. adj. enoikos, inhabiting; N.L. fem. adj. enoeca, inhabiting, because the organism is an inhabitant of the gingival crevice). The description below is based on studies of the type strain and seven other isolates obtained from six other people. Cells of the type strain are $0.5 \mu \mathrm{m}$ wide by 2.2 to 4.6 $\mu \mathrm{m}$ long; filaments up to $7.7 \mu \mathrm{m}$ long are observed. Cells are not motile and occur in pairs and short chains. Surface colonies on rabbit blood agar plates incubated for 2 days are 1 to $2 \mathrm{~mm}$ in diameter, circular, entire, convex, transparent to translucent, and not hemolytic. No pigment develops on either hemolyzed or whole rabbit blood agar plates or streak tubes incubated for 10 days, and there are no hemolytic zones around colonies on blood agar plates. Broth cultures are turbid with a smooth sediment. The terminal $\mathrm{pH}$ values of glucose broth cultures incubated for 5 days are 4.8 to 5.4.

The fermentation acids are succinic acid $(3.2 \pm 0.72 \mathrm{meq} /$ $100 \mathrm{ml}$ of culture [mean \pm standard error of the mean]) and acetic acid $(1.4 \pm 0.19 \mathrm{meq} / 100 \mathrm{ml})$; sometimes a trace of

TABLE 4. Cellular fatty acid contents at greater than $5 \%$ of the total acids

\begin{tabular}{|c|c|c|c|c|c|c|c|c|}
\hline \multirow[b]{2}{*}{ Taxon } & \multicolumn{8}{|c|}{ Fatty acid content $(\%)$} \\
\hline & iso- $\mathrm{C}_{14: 0}$ & $\mathrm{C}_{14: 0}$ & iso- $\mathrm{C}_{15: 0}$ & anteiso- $\mathrm{C}_{15: 0}$ & $C_{16: 0}$ & $30 \mathrm{H} \mathrm{C} \mathrm{C}_{16: 0}$ & iso- $\mathrm{C}_{17: 0}$ & $\begin{array}{c}3 \mathrm{OH} \text { iso- } \\
\mathrm{C}_{17: 0} \text { or } \mathrm{C}_{18: 2} \\
\text { dimethyl acetyl }\end{array}$ \\
\hline Prevotella spp. $^{a}$ & $5(0-13)$ & $2(0-9)$ & $10(4-18)$ & $35(22-45)$ & $9(2-24)$ & $5(1-13)$ & $3(3-9)$ & $11(5-18)$ \\
\hline P. tannerae & 3 & 5 & 20 & 30 & 6 & 3 & 2 & 12 \\
\hline P. enoecae & 3 & 4 & 8 & 36 & 17 & 10 & 2 & 5 \\
\hline P. zoogleoformans & 0 & 1 & 16 & 25 & 12 & 5 & 5 & 15 \\
\hline
\end{tabular}

${ }^{a}$ The values for Prevotella spp. are the means (and ranges) obtained for the following species and subspecies: $P$. bivia, $P$. buccae, $P$. buccalis, $P$. corporis, $P$. denticola, $P$. disiens, $P$. heparinolytica, $P$. intermedia, $P$. loescheii, $P$. melaninogenica, $P$. nigrescens, $P$. oralis, $P$. oris, $P$. oulora, $P$. numinicola subsp. ruminicola, $P$. veroralis, and $P$. zoogleoformans. Data were obtained from reference 8 . 
TABLE 5. Incidence of $P$. tannerae, $P$. enoeca, and $P$. zoogleoformans in gingival crevice samples

\begin{tabular}{|c|c|c|c|c|c|c|c|c|c|}
\hline \multirow{3}{*}{ Population } & \multirow{3}{*}{$\begin{array}{l}\text { No. of } \\
\text { people }\end{array}$} & \multicolumn{4}{|c|}{ Occurrence } & \multicolumn{4}{|c|}{ Isolates } \\
\hline & & \multirow{2}{*}{$\begin{array}{c}\text { No. of } \\
\text { samples }^{a}\end{array}$} & \multicolumn{3}{|c|}{$\%$ of samples positive for: } & \multirow{2}{*}{$\begin{array}{l}\text { No. of } \\
\text { isolates }\end{array}$} & \multicolumn{3}{|c|}{$\%$ of isolates positive for: } \\
\hline & & & P. tannerae & P. enoeca & P. zoogleoformans & & P. tannerae & P. enoeca & P. zoogleoformans \\
\hline Healthy & 84 & 275 & 3.6 & 1.1 & 0 & 8,588 & 0.2 & 0.1 & 0 \\
\hline \multicolumn{10}{|l|}{ Experimental gingivitis } \\
\hline Adults & 4 & 96 & 1.0 & 0 & 0 & 3,038 & 0.03 & 0 & 0 \\
\hline Children & 4 & 102 & 2.9 & 0 & 0 & 3,215 & 0.1 & 0 & 0 \\
\hline $\begin{array}{l}\text { Naturally occurring } \\
\text { gingivitis }\end{array}$ & 11 & 22 & 0 & 0 & 0 & 680 & 0 & 0 & 0 \\
\hline Adult periodontitis & 93 & 399 & 11.0 & 0.5 & 0.5 & 12,571 & 0.7 & 0.02 & 0.02 \\
\hline $\begin{array}{l}\text { Rapidly progressive } \\
\text { periodontitis }\end{array}$ & 21 & 84 & 8.3 & 0 & 0 & 2,880 & 0.5 & 0 & 0 \\
\hline Juvenile periodontitis & 21 & 73 & 6.9 & 1.4 & 0 & 2,335 & 0.4 & 0.04 & 0 \\
\hline
\end{tabular}

${ }^{a}$ Each sample contained about 30 isolates.

formic acid is present. No hydrogen is detected in the headspace gas of glucose broth cultures.

Additional characteristics of the species are shown in Tables 2 and 4.

Isolated from the gingival crevices of humans with healthy gingiva and periodontitis (Table 5).

The type strain is ATCC $51261^{\mathrm{T}}$ (= VPI D194A-25A).

The $\mathrm{G}+\mathrm{C}$ content of the DNA of the type strain is $47 \mathrm{~mol} \%$.

The lack of sucrose fermentation and the inability of $P$. enoeca to digest gelatin differentiate this species from many Prevotella species (Table 3). It can be differentiated from $P$. tannerae by its cellular fatty acid profile (iso- $\mathrm{C}_{15: 0}$ fatty acid content) (Table 4).

Description of Prevotella zoogleoformans (Weinberg et al. 1937) Shah and Collins 1990. The phenotypic characteristics of the type strain and four other strains of $P$. zoogleoformans are shown in Table 2 , and the characteristic cellular fatty acids of the species are shown in Table 4. Characteristics that differentiate $P$. zoogleoformans from some other Prevotella species are shown in Table 3 . Production of acid from cellobiose and usually from lactose and an inability to produce colonies with dark pigment on blood agar differentiate $P$. zoogleoformans from Prevotella intermedia and $P$. nigrescens, the other indole-producing strains in the genus.

The $\mathrm{G}+\mathrm{C}$ content of the DNA of the type strain, ATCC 33285 , is $47 \mathrm{~mol} \%$.

The incidence of the species in periodontally healthy and diseased individuals is shown in Table 5.

\section{ACKNOWLEDGMENTS}

We gratefully acknowledge the help of Sue C. Smith, Pauletta C. Atkins, Kimberly S. Bulls, and Colleen O. Ecker for microbiological studies, Ann P. Donnelly for electrophoretic and chromatographic studies, Dianne M. Bourne for cellular fatty acid analyses, Julianna Toth for assistance with the nucleic acid studies, and Phyllis V. Sparks for technical assistance. We are indebted to Thomas O. MacAdoo, Professor Emeritus, Virginia Polytechnic Institute and State University, for suggesting appropriate names for taxa and providing the etymologies. We appreciate critical reviews of the manuscript by J.-S. Chen and Roger Van Tassell.

This work was supported by Program Project grant DE 08972 from the National Institute of Dental Research, National Institutes of Health and by grant 135145 from the Cooperative State Research Service, U.S. Department of Agriculture.

\section{REFERENCES}

1. Bailey, G. D., L. V. H. Moore, D. N. Love, and J. L. Johnson. 1988. Bacteroides heparinolyticus: deoxyribonucleic acid relatedness of strains from the oral cavity and oral-associated disease conditions of horses, cats, and humans. Int. J. Syst. Bacteriol. 38:42-44.
2. Cato, E. P., R. W. Kelley, W. E. C. Moore, and L. V. Holdeman. 1982. Bacteroides zoogleoformans (Weinberg, Nativelle, and Prévot 1937) corrig., comb. nov.: emended description. Int. J. Syst. Bacteriol. 32:271-274.

3. Holdeman, L. V., E. P. Cato, and W. E. C. Moore (ed.). 1977. Anaerobe laboratory manual. Virginia Polytechnic Institute and State University Anaerobe Laboratory, Blacksburg.

4. Holdeman, L. V., and J. L. Johnson. 1977. Bacteroides disiens sp. nov. and Bacteroides bivius sp. nov. from human clinical infections. Int. J. Syst. Bacteriol. 27:337-345.

5. Holdeman, L. V., R. W. Kelley, and W. E. C. Moore. 1984. Bacteroides Castellani and Chalmers 1919, 959 ${ }^{\mathrm{AL}}$, p. 604-631. In N. R. Krieg and J. G. Holt (ed.), Bergey's manual of systematic bacteriology, vol. 1. The Williams \& Wilkins Co., Baltimore.

6. Holdeman, L. V., W. E. C. Moore, P. J. Churn, and J. L. Johnson. 1982. Bacteroides oris and Bacteroides buccae, new species from human periodontitis and other human infections. Int. J. Syst. Bacteriol. 32:125-131.

7. Johnson, J. L. 1994. Similarity analysis of DNAs, p. 655-682. In P. Gerhardt, R. G. E. Murray, W. A. Wood, and N. R. Krieg (ed.), Methods for general and molecular bacteriology. American Society for Microbiology, Washington, D.C.

8. Moore, L. V. H., D. M. Bourne, and W. E. C. Moore. 1994. Comparative distribution and taxonomic value of cellular fatty acids in thirty-three genera of anaerobic gram-negative bacilli. Int. J. Syst. Bacteriol. 44:338-347.

9. Moore, W. E. C., D. E. Hash, L. V. Holdeman, and E. P. Cato. 1980. Polyacrylamide slab gel electrophoresis of soluble proteins for studies of bacterial floras. Appl. Environ. Microbiol. 39:900-907.

10. Moore, W. E. C., and L. V. H. Moore. 1994. The bacteria of periodontal diseases, p. 66-77. In S. S. Socransky and A. D. Haffajee (ed.), Periodontology 2000, vol. 5. Munksgaard, Copenhagen.

11. Paster, B. J., F. E. DeWhirst, I. Olsen, and G. J. Fraser. 1994. Phylogony of Bacteroides, Prevotella, and Porphyromonas spp. and related bacteria. J. Bacteriol. 176:725-732.

12. Prévot, A. R. 1938. Etudes de systématique bactérienne. Ann. Inst. Pasteur (Paris) 60:285-307.

13. Shah, H. N., and M. D. Collins. 1990 . Prevotella, a new genus to include Bacteroides melaninogencius and related species formerly classified in the genus Bacteroides. Int. J. Syst. Bacteriol. 40:205-208.

14. Shah, H. N., M. D. Collins, J. Watabe, and T. Mitsuoka. 1985. Bacteroides oulorum sp. nov., a nonpigmented saccharolytic species from the oral cavity. Int. J. Syst. Bacteriol. 35:193-197.

15. Skerman, V. B. D., V. McGowan, and P. H. A. Sneath (ed.). 1980. Approved lists of bacterial names. Int. J. Syst. Bacteriol. 30:225-420.

16. Watabe, J., Y. Benno, and R. Mitsuoka. 1983. Taxonomic study of Bacteroides oralis and related organisms and proposal of Bacteroides veroralis sp. nov. Int. J. Syst. Bacteriol. 33:57-64.

17. Wu, C.-C., J. L. Johnson, W. E. C. Moore, and L. V. H. Moore. 1992. Emended descriptions of Prevotella denticola, Prevotella loescheii, Prevotella veroralis, and Prevotella melaninogenica. Int. J. Syst. Bacteriol. 42:536-541. 